\title{
MENINGKATKAN KEMAHIRAN MOTORIK KASAR ANAK PRA SEKOLAH DI RA BAITUSSALAM CIMAHI MELALUI BERMAIN ANGKLUNG
}

\author{
Fitriyani Solihat ${ }^{1}$, Siti Yani Aisyah ${ }^{2}$ \\ ${ }^{1}$ RA Baitussalam, ${ }^{2}$ RA Miftahul Hayat \\ ${ }^{1}$ Jl. Pojok Selatan 1 RT 02 RW 07 Cimahi Tengah, ${ }^{2}$ Jl. Gandasoli RT 16 RW 06 Wanayasa \\ fitriyanisolihat@gmail.com, ${ }^{2}$ sitivaniaisyah27@gmail.com
}

\begin{abstract}
Learning activities in kindergartens was implemented through play activities. In carrying out the principle of learning in kindergarten there is a lot of learning strategies that can be use, one of them with "playing music". Play music including art activity for children kindergarten. When performing musical activities children can play several musical instruments as appropriate for kindergarten one IE tool music angklung. By playing the music will help the child express his feelings and creativity. The method used is the Class Action Research. This research was conducted in one of the kindergartens that are located in the village Setiamanah in the city of Cimahi. The research results obtained data about process of learning by playing angklung can improve motor rough early childhood. The recommendations of this study are: 1) for the school, the need for the provision of the infrastructure used to support the motor ability of the rough early childhood. 2) For Educators to know the use of musical instruments in developing motor abilities angklung rough early childhood.3) For instances of the Builder, as a reference about the strategy of playing the angklung motor ability in developing a rough early childhood. From the results of the study in this class Action was concluded that by playing angklung is a strategy that can be used to enhance the ability of a rough early childhood motor.
\end{abstract}

Keywords: angklung, gross motoric

\begin{abstract}
Abstrak
Kegiatan pembelajaran di RA dilaksanakan melalui kegiatan bermain. Dalam menjalankan prinsip pembelajaran di RA ada banyak strategi pengkajian yang boleh digunakan, salah satunya dengan "bermain musik". Bermain musik termasuk aktivitas seni untuk anak RA. Saat melakukan kegiatan bermusik anak dapat memainkan beberapa alat musik yang sesuai untuk anak RA yaitu angklung. Dengan bermain musik akan menunjang anak mengartikulasikan perasaannya dan kreativitas. Metode yang digunakan adalah PTK. Penelitian ini dilakukan di RA yang berada di Kelurahan Setiamanah di Kota Cimahi. Hasil penelitian diperoleh data mengenai proses pembelajaran dengan bermain angklung dapat memajukan kemahiran motorik kasar anak pra sekolah. Rekomendasi penelitian ini diantaranya : 1) Bagi sekolah, perlunya penyediaan sarana prasarana yang dipakai untuk menunjang kemahiran motorik kasar anak pra sekolah. 2) Bagi Pendidik untuk mengetahui pemakaian alat musik angklung dalam menumbuhkan kemahiran motorik kasar anak pra sekolah. 3) Bagi Instansi Pembina, sebagai referensi tentang strategi bermain angklung dalam menumbuhkan kemahiran motorik kasar anak pra sekolah. Dari hasil PTK ini disimpulkan bahwa dengan bermain angklung adalah suatu cara yang bisa digunakan untuk menunjang kemahiran motorik kasar anak pra sekolah.
\end{abstract}

Kata Kunci: angklung, motorik kasar

\section{PENDAHULUAN}

Pendidikan mempunyai peranan penting yang sangat menentukan dalam pertumbuhan dan perkembangan diri individu seorang anak.
Bermaknanya pendidikan diberikan pada anak pra sekolah terdapat dalam Undang-undang Sisdiknas No.20 tahun 2003, PAUD pasal 1 ayat 1 , dinyatakan bahwa "PAUD adalah suatu upaya pembinaan yang ditujukan kepada anak sejak 


\section{JURNAL CERIA}

lahir sampai berusia 6 tahun yang dilakukan melalui pemberian rangsangan pendidikan untuk membantu pertumbuhan dan perkembangan jasmani dan rohani agar anak memiliki kesiapan dalam memasuki pendidikan lebih lanjut". PAUD merupakan aktivitas belajar sambil bermain yang dilakukan pada usia pra sekolah, lebih pada menumbuhkan keberanian anak serta memberikan stimulus yang tepat bagi anak.Melihat hal tersebut Suryaman (2005:80) mengungkapkan bahwa anak usia 4-6 tahun merupakan bagian dari anak usia dini yang secara terminology disebut anak usia prasekolah.

Motorik kasar adalah aktivitas dengan menggunakan otot-otot besar yang meliputi gerak dasar lokomotor, non lokomotor, danmanipulatif sedangkan yang dimaksud dengan motorik halus adalah kemampuan anak pra sekolah beraktivitas menggunakan otot-otot halus (otot kecil) seperti menulis, menggambar dan lain-lain (Samsudin: 2005).Untuk memvariasikan berbagai kegiatan motorik kasar guru biasa melakukan kegiatan seperti berjalan, berlari, merangkak, engkle, melompat, menendang dan sebagainya, tapi ternyata ada pilihan lain dalam memajukan kemahiran motorik kasar, diantaranya yaituanak berkecimbung dengan alat-alat musik dan menyediakan kesempatan untuk bermain musiktertentu yaitu dengan bermain angklung, dengan bermain angklung anak boleh menggerakan tubuh secara terkoordinasi untuk melatih kelenturan, keseimbangan dan kelincahan, mampu melakukan permainan fisik dengan aturan, terampil menggunakan tangan kanan dan kiri. Usia RA adalah moment yang cocok untuk mempersilahkan memainkan musik, karena tahap usia inilah berlangsung pertambahan pendengaran anak yangpesat. Untuk menambahkan kemahiran motorik anak, dapat memakai alat-alat musik yang ringan dan cocok dipakai anak yakni angklung.

Angklung merupakan alat musik tradisional terbuat dari bambu dan dimainkan dengan cara digoyangkan. Ansor (dalam Indriani, 2005: 14) mengemukakan keunggulan dari alat musik angklung, yaitu untuk memainkan alat musik tersebut pemain tidak dituntut untuk memiliki keterampilan dan bakat tertentu, sehingga hampir semua orang diyakini dapat memainkan alat ini.

Berdasarkan observasi yang sudah pernah dikerjakan oleh penulis, diperoleh informasi bahwa kemampuan anak-anak RA Baitussalam usia pra sekolah belum maksimal dalam menggerakkan dan menggoyangkanangklung, hanya 2 dari 15 anak yang mampu memainkan dengan kriteria baik.

Berdasarkanuraian di atas, maka penulis tergerak melakukanpengkajian tentang "Meningkatkan kemahiran motorik kasar anak usia pra sekolah di RA Baitussalam Cimahi Melalui Bermain Angklung."

\section{METODE PENELITIAN}

PTK dilaksanakan selama 5 bulan, dari 8 januari 2018 sampai dengan 4 Mei 2018.Dengan subyek penelitiannya anak didik sebanyak 15 orang, Metode pengumpulan data dengan observasi dengan instrumen berupa daftar cek, dokumentasi dan kepustakaan. Setelah pengetesan tahap awal dilaksanakan dapat diketahui kemampuan kreativitas awal anak, kemudian dilanjutkan dengan rencana perbaikan pada siklus ke I dilaksanakan sebanyak $3 x$ tatap muka, apabila pada siklus ke I peningkatan anak minimalsebanyak $60 \%$ belum terpenuhi maka disambung pada siklus ke II dengan $3 x$ pertemuan minimum mencapai target $60 \%$, apabila pada siklus II peningkatan kemampuan terpenuhi maka penelitian dinyatakan selesai.PTK di mulai dengan perencanaan, observasi dan refleksi dengan alur pelaksanaan tindakan seperti gambar 1 . 


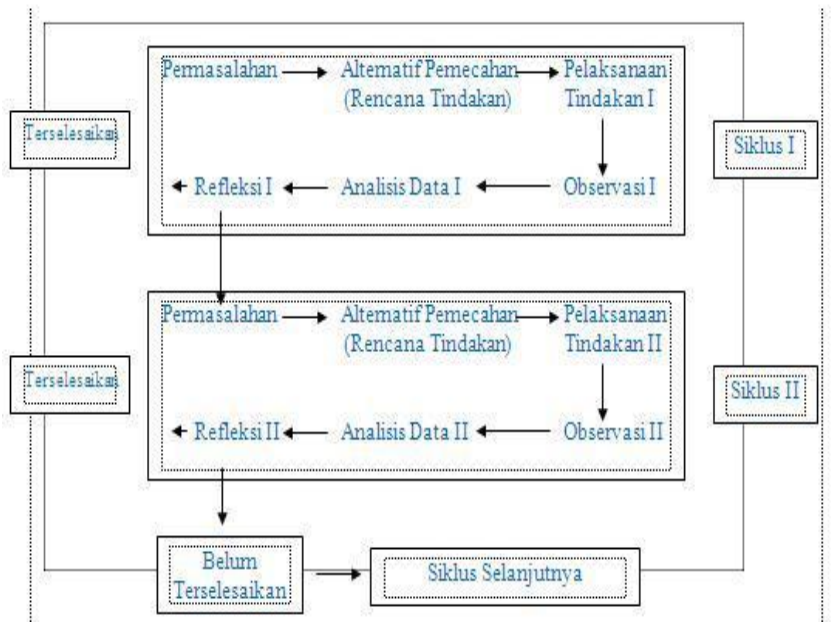

Gambar 1.Alur Pelaksanaan Tindakan

\section{PEMBAHASAN DAN HASIL PENELITIAN}

Pra sekolah ialah kelompok tahap usiapada dunia bermain dalam rentang usia 0-6 tahun. Proses bermain yang dilakukan anak pra sekolah dapat menambah pengalaman mengenai hal-hal baru yang kemudian diproses menjadi sebuah informasi bagi dirinya. Melalui bermain, anak dapat bebas bergerak dan menumbuhkan kemahiran motorik kasar serta halus, menjadikan badan sehat karena banyak bergerak. Perkembangan motorik berjalan sesuai dengan tahapan usia. Individu bergerak ke arah motorik yang lebih rinci dan terarah dengan baik.Perkembangan motorik menjadi salah satu hal yang penting bagi anak.

Perkembangan motorik mempengaruhi aspek-aspek perkembangan lainnya. Motorik adalah segala sesuatu yang bersangkutan dengan gerakan-gerakan tubuh. Perkembangan dan pertumbuhan merupakan faktor yang mempengaruhi kemampuan gerak dasar anak. Seperti dikemukakan Sugiyanto (1998: 251) bahwa gerak dasar fundamental adalah gerakangerakan dasar yang berkembangnya sejalan dengan pertumbuhan dan tingkat kematangan anak-anak. Namun hal yang berbeda, kemahiran gerak dasar tidak hanya dipengaruhi oleh perkembangan dan pertumbuhan saja, tetapi dipengaruhi oleh faktor lainnya seperti latihan.

Setiap anak memiliki insting untuk bermain, yaitu kebutuhan untuk berkreativitas dalam pola tertentu yang sangat membantu proses pertumbuhan dan perkembangannya (Miller dalam Mulyadi, 1997:9). Dalam upaya memajukan kemahiran motorik anak, dengan bermain angklung mewujudkan hal yang layak untuk dijadikan alat oleh guru dalam mendidik anak-anaknya terutama siswa RA.

Angklung adalah alat musik tradisional Indonesia yang berasal dari jawa Barat yang terbuat dari bambu, yang dibunyikan dengan cara digoyangkan dengan memiliki mata charisma di mata Internasional yaitu murah, sederhana, unik dan berpendidikan seni. Bunyi yang dihasilkan disebabkan oleh benturan badan bambu yang berbentuk seperti pipa, sehingga menghasilkan suara bergetar. Bunyi angklung yang sahut menyahut yang digoyangkan oleh beberapa orang akan terdengar lebih indah dan unik. Karena itulah angklung penuh dengan unsur pendidikan, bukan sekedar bermain musik tetapi terdapat proses belajar sambil bermain angklung sehingga dalam bermain angklung terkandung nilai gotong royong, disiplin, kreativitas, ketangkasan, konsentrasi dan tanggung jawab.

Proses pembelajaran angklung pada AUD akan berbeda dengan pembelajaran angklung biasa, karena subjek yang akan belajar angklung adalah AUD. Seiring dengan berjalannya pengkajian,angklung harus memiliki beberapa tahap belajar sebelum akhirnya anak memegang angklung. Tahap pertama adalah guru mensituasikan serta menyediakan angklung serta lagu dengan notasi angka yang berwarna-warni yang akan dipakaiwaktu jalannya pengkajianbermain angklung. Tahap kedua guru menyiapkan angklung sesuai dengan jumlah anak dan nada yang akan dimainkan. Tahap ketiga, guru menyarankan anak untuk menyeleksi angklung. Tahap keempat, guru mengkondisikan anak dan melakukan apersepsi sebagai upaya membangkitkan pengetahuan awal anak yang bersinggungan dengan lagu yang dinyanyikan menggunakan notasi angka yang berwarna-warni dan guru membangkitkan ingatan anak tentang lambang nada yang dipelajarinya. Tahap ke lima, guru memimpin permainan angklung sesuai lagu yang telah disiapkan. Tahap ke enam, guru harus mengubah suasana belajar menjadi arena bermain anak yang menyenangkan dengan cara meminta anak menggoyangkan angklung sesuai keserasian 
antara not angka serta angklung yang sudah diberi angka yang anak pegang. Misalnya guru menunjuk not dengan angka 5, maka anak yang memegang angklung dengan not angka 5 harus menggoyangkan angklung. Seperti ini penyampaian materi angklung dengan cara bermain akan membawa anak merasa nyaman untuk belajar. Proses pembelajaran angklung pada AUD dengan menggunakan angka yang memiliki fungsi sebagai media bermain angklung akan menarik perhatian anak dalam menggoyangkan angklung. Angka yang berwarna-warni ini lah yang akan diperhatikan anak dalam memainkan lagu dengan menggunakan angklung.Angklung yang dimainkan anak terkadang bunyi suaranya kurang terdengar keras karena gerakan tangan anak berbeda dengan gerakan tangan orang dewasa.

Subjek pengkajiannya pada anak pra sekolah dengan jumlah 15 anak, laki-laki 9 anak dan perempuan 6 anak. Dengan kegiatan bermain angklung ini diharapkan akan mampu menumbuhkan kemahiran motorik kasar anak.

Untuk mendapati kondisi awal anak maka dilakukan penelitian pra tindakan dan dari pra tindakan ini telah didapatkan hasil. Dari tabel data tersebut diperoleh hasil anak pada tahap belum berkembang ada 5 anak sebanyak $25 \%$ dan tahap MB terdapat10 anak sebanyak 43\%, pada tahap BSH dan BSB belum terdapat nilai. Ratarata kemahiran motorik kasar anak pra sekolah RA Baitussalam pada saat pra tindakan diperoleh rata-rata sebesar 39\%, sehingga di titik nilai MB .Sehingga disimpulkan masih rendahnya kemahiran motorik kasar anak dalam kegiatan bermain angklung karena masih ditemukan kurangnya kelenturan tangan anak dalam memegang dan mengayun angklung dengan benar sehingga anak belum mampu memainkan angklung dalam sebuah lagu sederhana.Berikut nilaites awal terlihat pada grafik 1

Grafik 1.

Penilaian Pra Tindakan

Menumbuhkan Kemahiran Motorik Kasar Melalui Kegiatan Bermain Angklung

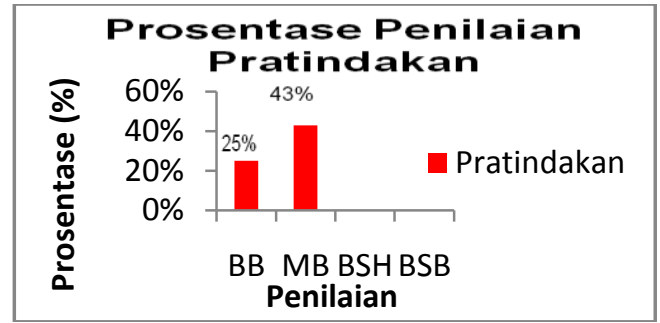

Pengkajian dilangsungkan ke pelaksanaan siklus I dengan tiga kali pertemuan, hasil yang didapatkan dari 15 mengalami peningkatan bahwa anak yang masih belum berkembang sudah tidak terdapat, anak pada tahap MB ada 8 anak sebanyak 44\%, anak pada tahap BSH ada 6 anak sebanyak $61 \%$ dan anak pada BSB ada 1 anak sebanyak $89 \%$. Namun hal tersebut belum mencapai indikator yang ditentukan oleh peneliti yaitu $\geq 76 \%$, sehingga perlu adanya upaya penigkatan lanjut untuk menumbuhkan kemahiran motorik kasar anak melalui kegiatan bermain angklung.

\section{Grafik 2. \\ Penilaian Siklus I
Menumbuhkan Kemahiran Motorik Kasar Melalui Kegiatan Bermain Angklung

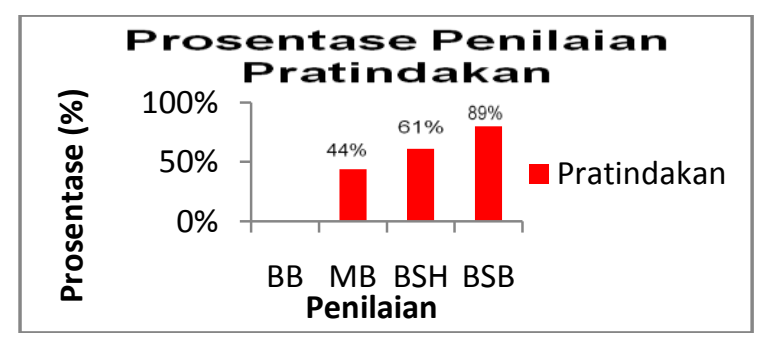

Pada penelitian siklus 1 meskipun sudah terdapan peningkatan, namun masih terdapat beberapa kendala, kurangnya anak fokus, dengan demikian perlu adanya perbaikan perencanaan yang akan dlaksanakan pada penelitian selanjutnya. Setelah perencanaan tersebut dibuat dan dilakukan koordinasi dengan guru, maka dilaksanakan penelitian tes siklus II yang dilakukan sebanyak 3x tatap muka. Melihat hasil yang telah didapatkan, terdapat peningkatan kemahiran motorik kasar anak, 8 anak yang sebelumnya mulai berkembang pada siklus I terjadi penurunan sebesar $44 \%$ menjadi $48 \%$, anak yang sudah BSH dari 6 anak $61 \%$ menjadi 


\section{JURNAL CERIA}

ISSN : 2614-6347 (Print) 2614-4107 (Online)

Vol.2 | No.2 | Maret 2019

$65 \%$, anak yang sudah BSB terdapat 4 anak dengan kondisi awal $89 \%$ menjadi 95\% terjadi peningkatan sebesar $15 \%$.

Pelaksanaan penelitian siklus II disusun sebaik mungkin dengan melakukan perbaikan perencanaan yang dikoordinasi dengan guru kelas yang bersangkutan untuk mengurangi rintangan dan ganjalandi siklus I.

\section{Grafik 3.}

Penilaian Siklus II

Menumbuhkan Kemahiran Motorik Kasar Melalui Kegiatan Bermain Angklung

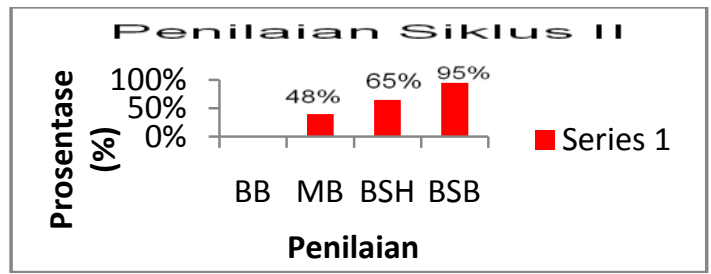

Pengkajian yang dikerjakan pada pra tindakan, siklus I sampai siklus II mengalami peningkatan kemahiran motorik kasar anak pra sekolah melalui kegiatan bermain angklung.Berikut ini tabel yang menjelaskan perbandingan kemahiran motorik kasar anak pada saat pra tindakan, siklus I serta siklus II adalah sebagai berikut:

Tabel 1.

Penilaian Rekapitulasi Nilai Kemahiran Motorik Kasar Melalui Kegiatan Bermain Angklung

\begin{tabular}{|c|c|c|c|}
\hline Kategori & $\begin{array}{c}\text { Pra } \\
\text { tindakan }\end{array}$ & Siklus I & Siklus II \\
\hline BB & $25 \%$ & $0 \%$ & $0 \%$ \\
MB & $43 \%$ & $44 \%$ & $48 \%$ \\
BSH & $0 \%$ & $61 \%$ & $65 \%$ \\
BSB & $0 \%$ & $89 \%$ & $95 \%$ \\
\hline
\end{tabular}

Pada data diatas diperoleh peningkatan kemahiran motorik kasar anak melalui kegiatan bermain angklung dari pra tindakan prosentase anak yang $\mathrm{BB}$ dari $25 \%$ menjadi $0 \%$, anak yang $\mathrm{MB}$ meningkat dari $43 \%$ menjadi $48 \%$, anak yang BSH meningkat dari $0 \%$ sekarang $65 \%$ dan yang BSB meningkat dari $0 \%$ menjadi $95 \%$.

Grafik 4.

Penilaian Rekapitulasi Nilai Kemahiran Motorik Kasar Melalui Kegiatan Bermain Angklung

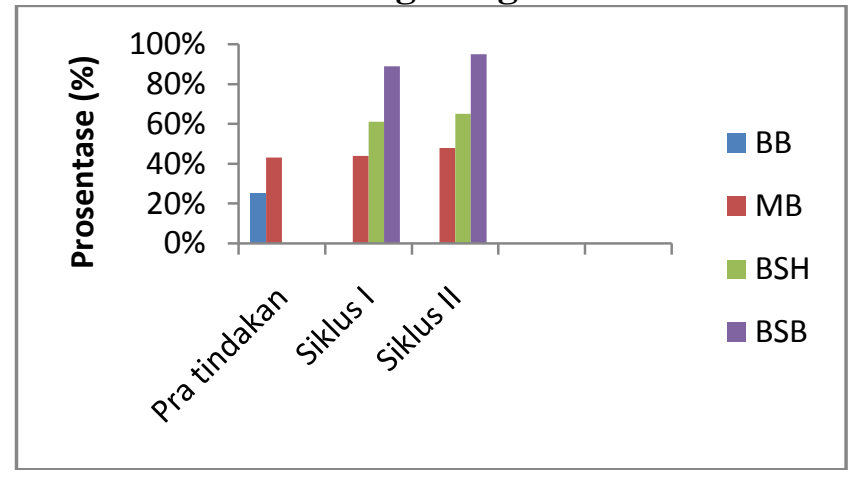

Berdasarkan grafik 4.diatas pengkajian yang dikerjakan pada pra tindakan, siklus I serta siklus II diperoleh peningkatan hasil pada kemahiran motorik kasar anak melalui bermain angklung.Pada penelitian pra tindakan diperoleh 5 anak yang BB dan 10 anak yang MB. Kemampuan motorik kasar anak rata-rata masih dibawah kriteria indikator keberhasilan , maka dari itu pengkajian dilangsungkan ke siklus I hal ini perlu adanya perbaikan supaya terjadi peningkatan yang menurut harapan. Pada penelitian siklus I diperoleh hasil anak yang BB sudah tidak ada, pada tahap MB ada 8 anak, pada tahap BSH ada 6 tahap dan terdapat penigkatan ke dalam BSB sebanyak 1 anak. Meskipun dari siklus I terdapat peningkatan yang baik tetapi hasilnya masih belum memenuhi kriteria keberhasilan yang diharapkan . Dari penelitian siklus ke II diperoleh hasil yang terlihat signifikan, anak yang $\mathrm{BB}$ ada 4 anak atau diprosentasekan sebesar $48 \%$, anak yang $\mathrm{BSH}$ ada 7 anak atau diprosentasekan sebesar $65 \%$ dan anak yang BSB ada 4 anak atau jika diprosentasekan sebesar $95 \%$.

\section{SIMPULAN}

Berlandaskan nilai PTK telah dilakukan, dan setiap siklusnya dilakukan langkah-langkah 


\section{JURNAL CERIA}

ISSN : 2614-6347 (Print) 2614-4107 (Online)

Vol.2 | No.2 | Maret 2019

perencanaan, pelaksanaan, pengamatan, dan refleksi. Disimpulkan bahwa penggunaan alat musik angklung dapat dipakai untuk menumbuhkan kemahiran motorik kasar AUD, penelitian ini ditunjukan dengan adanya peningkatan kemampuan motorik kasar anak usia dini sebesar 95\%, dengan demikian saran yang disampaikan kepada pendidik untuk lebih memahami dan mencari stimulus-stimulus utuk menumbuhkan kemahiran motorik kasar untuk AUD, sehingga anak menjadi semangat untuk mengikuti pembelajaran di kelas dengan pembelajaran bermain angklung boleh menerima kesan baru bagi anak. Pengalaman yang langsung didapat oleh anak adalah kunci yang dapat menumbuhkembangkan kecerdasan anak secara keseluruhan. Melalui kegiatan bermain angklung anak dapat melahirkanhal berlandaskan nilai imajinasinya, menguraikan sensitivitas sertamenilai produk kereasi seni, selain itu bagi peneliti yang sejenis yang dilakukan bisa dijadikan referensi bahwa melalui strategi bermain angklung boleh menumbuhkan kemahiran motorik kasar AUD.

\section{DAFTAR PUSTAKA}

Indriani, H. (2005). Penggunaan angklung pa da'eng dalam pembelajaran tangga nada minor di kelas dua SMP Negeri 1 Ciamis.Skripsi. Bandung: FPBS- UPI.

Mulyadi, S. 1997. Bermain itu penting. Jakarta:PT. Elex Media Kamputindo.

Suryaman, U. (2005). Pertumbuhan dan perkembangan anak.bandung: Alumni.

Samsudin. (2005). Pengembangan motorik di taman kanak- kanak. Jakarta: fakultas ilmu keolahragaan. Universitas negeri Jakarta

Sugiyanto. (1998). Perkembangan dan belajar motorik.Jakarta: Depdikbud

Undang-Undang Sisdiknas No 20 Tahun Tahun 2003 PAUD Ayat 1 Pasal 1 